\title{
原子炉配管溶接部における残留応力の不確かさ評価に 基づく確率論的構造健全性評価*
}

\author{
勝山 仁哉**, 伊藤 裕人***, 飛田＼cjkstart徹***, 鬼沢 邦雄*** \\ Probabilistic Structural Integrity Assessment Based on Uncertainty of Weld Residual Stress \\ at the Piping Butt-Welds of Nuclear Reactor Components* \\ by KATSUYAMA Jinya**, ITOH Hiroto***, TOBITA Tohru*** and ONIZAWA Kunio***

\begin{abstract}
Stress corrosion cracking (SCC), which affects the structural integrity of reactor component, has been observed at some piping joints made by austenitic stainless steel in BWR plants. It is well known that the SCC behavior is significantly scattered depending upon the various conditions such as materials, piping geometry, crack growth rate, weld residual stress, and so on. Since probabilistic fracture mechanics (PFM) analysis method treats such scatter and uncertainties in the structural integrity evaluation, it is, therefore, useful to apply the PFM analysis to the evaluation of the piping integrity. In JAEA, the PFM analysis code of PASCAL-SP for aged piping has been developed based on Monte Carlo method as described in our previous paper'). Among the conditions related to SCC behavior, weld residual stress near the welded joint is one of the most important factors to assess the structural integrity of piping because the tensile residual stress becomes a driving force of a SCC. Welding conditions such as heat input, welding speed and piping geometry affect weld residual stress distribution at the welded joint of piping. Effect of the welding conditions on the weld residual stress distribution has not yet been evaluated quantitatively. Hence, in this study, an effect of uncertainty of welding conditions, such as scatters of heat input and welding speed during welding, on weld residual stress at the piping buttwelds was evaluated using the simulation method by varying the welding conditions. Probabilistic fracture mechanics analysis using PASCALSP was also performed to evaluate the effect of uncertainty of weld residual stress on the break probability of piping. It was clarified that the break probability increased with increasing the uncertainties of residual stress.
\end{abstract}

Key Words: weld residual stress, stress corrosion cracking, structural integrity, probabilistic fracture mechanics, finite element method, thermoelastic-plastic analysis

\section{1. 緒言}

我が国のいくつかの軽水型原子力発電プラントでは30年 を超える運転が行われており，更に40年を超える長期間の 運転も検討されている。安全上重要な構造機器に対しては, 経年劣化を考慮した上で健全性を確認し, 安全の確保を図 る必要がある。安全性の評価には確率論的手法が使用され るが，原子炉冷却材圧力バウンダリを構成する原子炉圧力 容器や配管のように安全上重要な機器に対しても, 健全性 評価の技術的根拠として機器の破損確率を定量的に評価し ておくことが必要であると考えられる，構造健全性評価に おいては，合理的に配管の漏えいや破断確率等を評価する 手法として確率論的破壊力学 (PFM) 解析手法が近年用い られ，その有用性が示されている ${ }^{1)}$.（独）日本原子力研究 開発機構（JAEA）では, 重要構造機器の破損に関する合理 的な評価を行う一環として, PFM 解析に基づく確率論的構

\footnotetext{
*受付日 平成 22 年 2 月 17 日 受理日 平成 22 年 5 月 25 日 平成 21年度溶接構造シンポジウムで発表

**正 員 (独) 日本原子力研究開発機構 Member, Japan Atomic Energy Agency

**** (独) 日本原子力研究開発機構 Japan Atomic Energy Agency
}

造健全性評価技術の開発・整備を進めている，原子炉冷却 材圧力バウンダリ配管溶接部を対象としては，PFM 解析コ ード PASCAL-SP (PFM Analysis of Structural Components in Aging LWR - Stress Corrosion Cracking at Welded Joints of Piping）を開発している ${ }^{2}$. PASCAL-SP の開発にあたり，確 率論的評価モデルに関する試験データ等の調査を行い, PFM解析に必要な評価モデルとして応力腐食割れ（SCC; Stress Corrosion Cracking）の発生及びその進展速度，供用期 間中検査等に対する解析手法を整備している。オーステナ イト系ステンレス鋼配管溶接部における SCC を対象とする 場合, 構造健全性評価においてはき裂の発生・成長を支配 する材料・環境・学因子の取り扱いが重要である. 力学 的観点からは，配管内表面及び肉厚内の残留応力分布が $\mathrm{SCC}$ の発生とその後の進展速度や方向に大きな影響を及ぼ すため，これを精度よく評価する必要がある。ただし，残 留応力は, 溶接施工時の溶接条件や最終仕上げ等の不確か さに伴うばらつきを有しているため, 残留応力の分布及び そのばらつきを把握することは，構造健全性評価の観点か ら重要な課題の 1 つである。そこで本研究では, PASCALSPにおいて使用する確率論的な溶接残留応力評価モデルを 作成するため，配管突合せ溶接部を対象として，溶接施工 時における入熱量や溶接速度等の溶接条件デー夕を取得す るとともに，取得したデータに基づき溶接条件を変化させ 
た有限要素法（FEM）による熱弾塑性解析を実施し，それ らの不確かさが溶接残留応力に及ぼす影響を評価した。ま た，作成した溶接残留応力評価モデルをPASCAL-SP に導 入し, 溶接残留応力に関わる不確かさが配管の破断確率に 及ぼす影響に関する検討を行った。

\section{2. 配管溶接部における残留応力評価及び構造健全性評価}

\section{1 配管溶接部試験体製作及び残留応力測定}

溶接施工時において，同一の溶接条件を設定した場合に おける溶接条件の不確かさを把握するため, 下向き自動 TIG 溶接により 10 体の $250 \mathrm{~A} \operatorname{sch} 80$ 管の突合せ溶接部試験体 （5 層 8 パス）を製作した。製作した試験体の形状及び開先 形状を Fig. 1 に示す。溶接部試験体の管材料及び溶接材料 は，オーステナイト系ステンレス鋼 SUS316 である。また，
溶接条件として，入熱条件は $18 \mathrm{~kJ} / \mathrm{cm}$ 以下，パス間温度は $150^{\circ} \mathrm{C}$ 以下に設定した。溶接条件のばらつきを評価するた め，すべての試験体製作時に，溶接施工中の電流，電圧及 び溶接速度を測定した。また，伝熱解析の精度を検証する ため，溶接部近傍の内表面及び外表面において，熱電対に より温度履歴を測定した。さらに，熱弾塑性解析による溶 接残留応力シミュレーションの精度を検証するため, X 線 回折法及び応力解放法により，製作した配管溶接部試験体 の内表面及び外表面における残留応力測定を行った。

\section{2 残留応力解析}

入熱量や溶接速度等の溶接条件の不確かさが残留応力分 布に及ぼす影響について評価するため，2.1で述べた配管溶 接部試験体に対応した FEM 解析用のモデルを作成し，熱弾 塑性解析による溶接シミュレーションを行った。ここで，
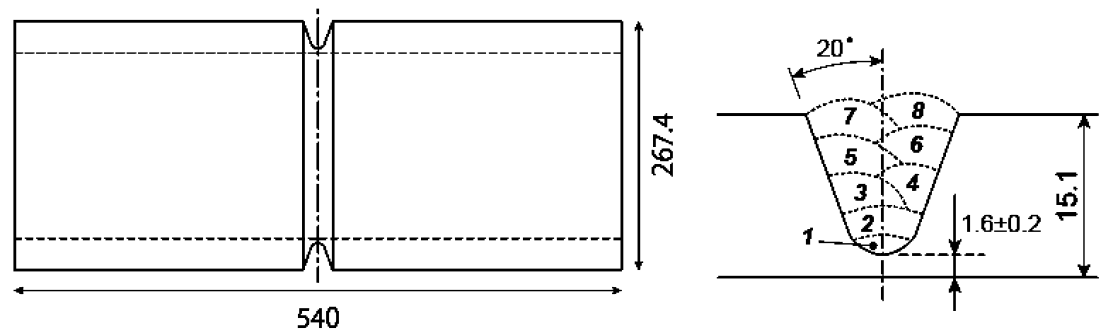

Fig. 1 Shapes of weld specimen and groove (Unit: $\mathrm{mm}$ )

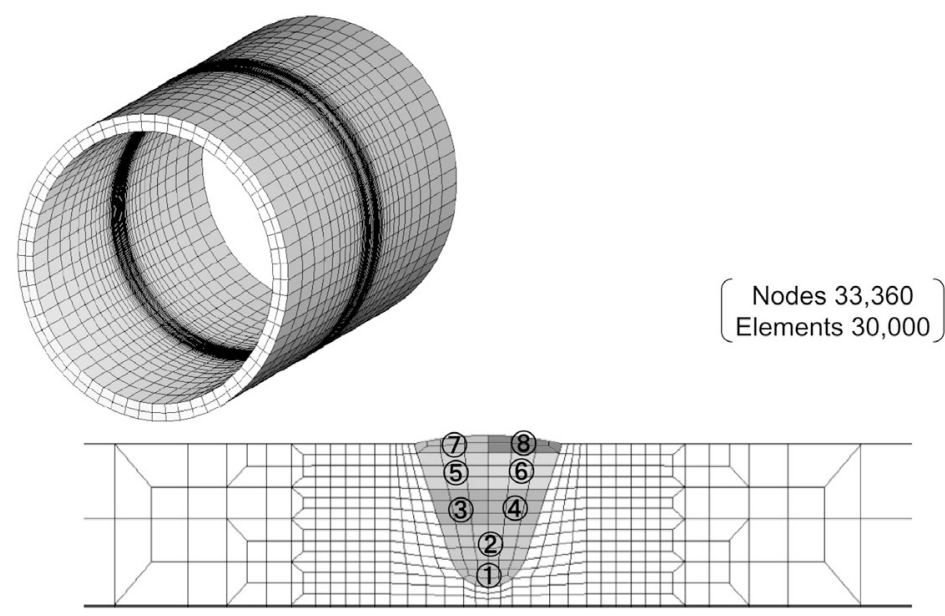

(a) Three dimensional model

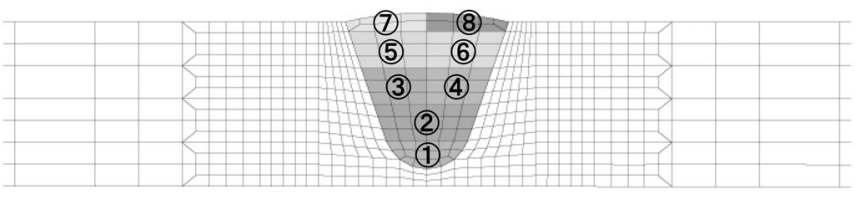

(b) Axisymmetric model

Fig. 2 Three-dimensional and axisymmetric analytical models for butt welding of 250A piping. 
溶接シミュレーションは, 沉用 FEM 解析コード Abaqus ${ }^{3}$ を 用いた非定常伝熱解析及び大変形非線形熱弾塑性解析から 構成される。本研究において作成した三次元及び軸対称モ デルの要素分割を Fig. 2 に示す. 軸対称モデルは, 三次元 モデルの断面と同じ形状である。製作した試験体の溶接条 件に合わせて，図に示すとおり 5 層 8 パスの溶接をモデル 化した. Fig. 3 に示すような溶接熱源（二重棈円モデル $\left.(\text { Goldak モデル })^{4)}\right)$ を，溶接開始とともに $0^{\circ}$ 位置から移動 を開始させ，時間とともに周方向に移動させた後，開始点 と同一位置にて停止させた。軸対称モデルでは，熱源を FEM モデルに対して垂直方向に通過させた. 両モデルとも， 溶接熱源の通過と同時に溶接金属となる要素を追加するこ とにより，溶接金属の付着を模擬している. Fig. 3 の熱源形 状パラメー夕は，溶融池の形状から自動的に決定できる． $\mathrm{a}_{\mathrm{f}}$ 及び $\mathrm{a}_{\mathrm{r}}$ はそれぞれ熱源中心より前方及び後方の溶融池の長 さに依存し，実際の熱源を考慮すると $\mathrm{a}_{\mathrm{f}}: \mathrm{a}_{\mathrm{r}}=1: 1.5 \sim 2$ 程度 になる. b 及び $\mathrm{c}$ は熱源の進行方向に垂直な棈円の長軸及 び短軸に相当し，溶接部の断面をマクロ観察して得られた 溶け込み形状により決定した。また，入熱量パラメータ $\left(\mathrm{Q}=\mathrm{Q}_{\mathrm{f}}+\mathrm{Q}_{\mathrm{r}}\right)$ は, 本研究では電圧 $\times$ 電流に熱効率を乗じた ものとして定義し, その平均值及び標準偏差は, 断熱条件 により伝熱解析から求められる入熱量が，実測により得ら れた入熱量（入熱量 $=($ 電圧 $\times$ 電流 $) /$ 溶接速度 $)$ に等しく なるように，溶接パスごとに決定した．ここで， $\mathrm{Q}_{\mathrm{f}}: \mathrm{Q}_{\mathrm{r}}=2$ ：1 が常に成り立つものとした。これにより，実施工で生じ る溶接条件の不確かさが溶接残留応力に及ぼす影響を評価 可能となる，溶接後の冷却時間は，溶接部試験体を製作し た際の温度履歴データに基づき決定した．材料物性值には， 試験体材料であるオーステナイト系ステンレス鋼 SUS316 のデータを使用し，すべての物性值（伝熱解析に用いた熱伝 導率, 比熱及び密度, 並びに熱弾塑性解析に用いたヤング率, 降伏応力, 加工硬化係数及び線膨張係数) について温度依存 性を考慮した。なお，母材と溶接金属の材料物性は同じもの とした。また，材料の溶融温度に関しては， $1400{ }^{\circ} \mathrm{C}$ 以上と なった要素の背応力及び塑性歪はゼロになるものとした。

溶接条件が残留応力に及ぼす影響を詳細に評価するため, まず溶接部試験体製作時に取得した溶接条件に基づく溶接 残留応力解析を行い，三次元及び軸対称モデルにおける本
解析手法の妥当性を確認する．PFM 解析に用いる確率論的 な残留応力評価モデルを作成するためには，溶接条件のば らつきに関する膨大なケースの解析を要する。このため, 解析に長時間要する三次元モデルについては，数ケースの 解析により，溶接条件の不確かさが残留応力のばらつきに 及ぼす影響についての基本的な知見を得る。その結果を踏 まえ, 軸対称モデルを用いて効率的にパラメトリック解析 を行い, PFM 解析に供する確率論的な残留応力評価モデル を構築する．溶接条件の不確かさについては，入熱パラメ 一夕と溶接速度に着目し，これら溶接条件の変化が溶接残 留応力分布に及ぼす影響について評価する。ここで，入熱 量パラメータ $\mathrm{Q}$ は，前述のとおり電圧×電流に熱効率を乗 じたものであるため，溶接速度とは独立のパラメータとし て取り扱う。

\subsection{PFM 解析}

PASCAL-SP は，配管の溶接残留応力分布とそのばらつき に加え，SCCの進展及び合体，地震荷重等を考慮して破損 確率等を評価することが可能である，本研究では，前述の 溶接残留応力解析結果を基に作成した残留応力評価モデル をPASCAL-SP に導入して，配管の破損確率に関する PFM 解析を実施したＳCCによるき裂進展や破断判定等は，原 子力安全・保安院の報告書 ${ }^{5}$ 及び日本機械学会の維持規格 ${ }^{6}$ に準拠している. Fig. 4 にPASCAL-SP における破損確率解 析のフローチャートを示す。解析条件として幾何形状や運 転荷重等を設定した後，SCCによるき裂進展・合体，供用 期間中検査，地震荷重によるき裂進展等を模擬する．破断 判定は破断クライテリアとして極限荷重評価法を用いた. 破断や漏えいに至る確率は，各種の確率変数を乱数を用いて サンプリングし，プラントの長期運転を模擬して SCC のき 裂進展解析と破断の可能性を判定するという一連の健全性評 価を繰り返す，いわゆるモンテカルロ法によって評価する.

$250 \mathrm{~A}$ 配管を対象として実施した PFM 解析の主な解析条 件を Table 1 に示す. FEM 解析に基づく残留応力評価モデ ルを用いて残留応力の不確かさが破断確率に及ぼす影響に ついて評価を行う。なお，本研究では，残留応力の不確か さに着目するため，Table 2 に記すパラメータにのみ確率分 布を与え，その他の条件は一定值を与えた。

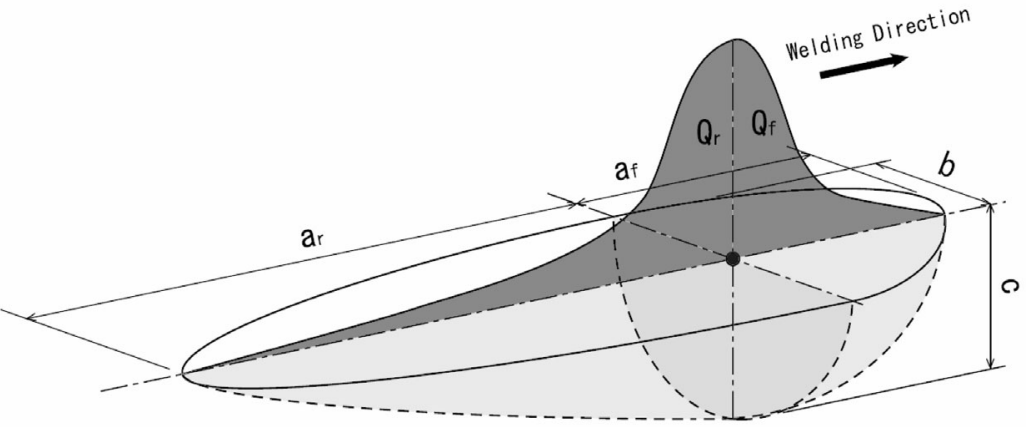

Fig. 3 Heat source model ${ }^{4)}$. 


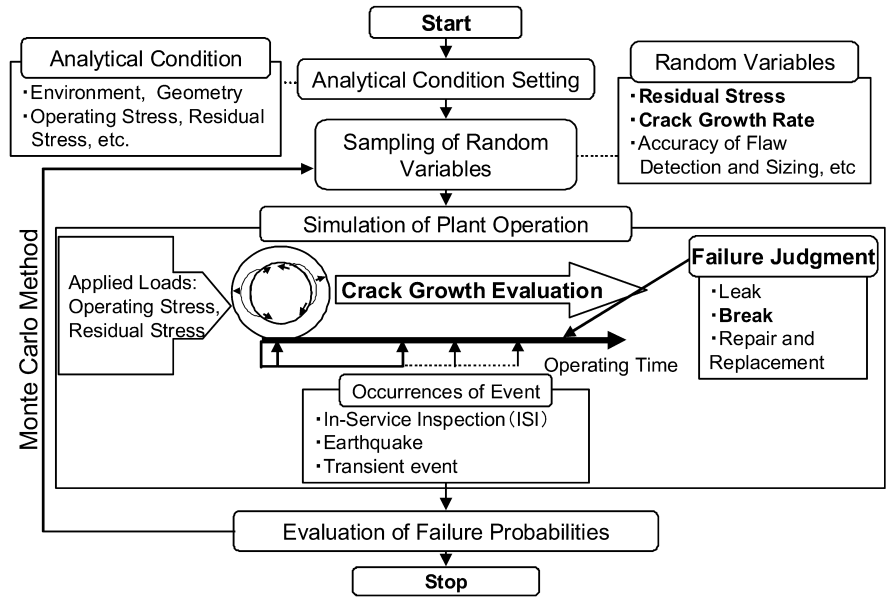

Fig. 4 Flowchart of probabilistic fracture mechanics analysis in PASCAL-SP.

Table 1 Analytical conditions of PFM analysis for 250A piping.

\begin{tabular}{|l|l|}
\hline Piping Geometry & 250A ( $\phi 267.4 \mathrm{~mm}$, thickness $15.1 \mathrm{~mm})($ Type $316 \mathrm{~L})$ \\
\hline Material & Type $316 \mathrm{~L}$ stainless steel \\
\hline Residual Stress Distribution & Probabilistic model described in 3.3 \\
\hline Crack Initiation & Pre-existing one crack (depth $0.7 \mathrm{~mm}$, length 15.5mm) \\
\hline Crack Growth Rate by SCC & $\begin{array}{l}\text { Based on the experimental data in the annex of JSME Rules on } \\
\text { Fitness-for-Service }\end{array}$ \\
\hline Mechanical failure Judgment & Net section collapse criteria in JSME Rules on Fitness-for-Service \\
\hline
\end{tabular}

Table 2 Probabilistic variables in PFM analyses by PASCAL-SP.

\begin{tabular}{|l|l|l|}
\hline \multicolumn{1}{|c|}{ Category } & \multicolumn{1}{|c|}{ Probabilistic Variable } & \multicolumn{1}{c|}{ Distribution } \\
\hline \multirow{2}{*}{ ScC } & Crack Initiation Position at Inner Surface of Piping & Normal Distribution \\
\cline { 2 - 3 } & Crack Growth Rate & Log-normal Distribution \\
\hline Stress & Though-thickness Distribution of Residual Stress & Normal Distribution \\
\hline Material Property & Flow Stress & Weibull Distribution \\
\hline
\end{tabular}

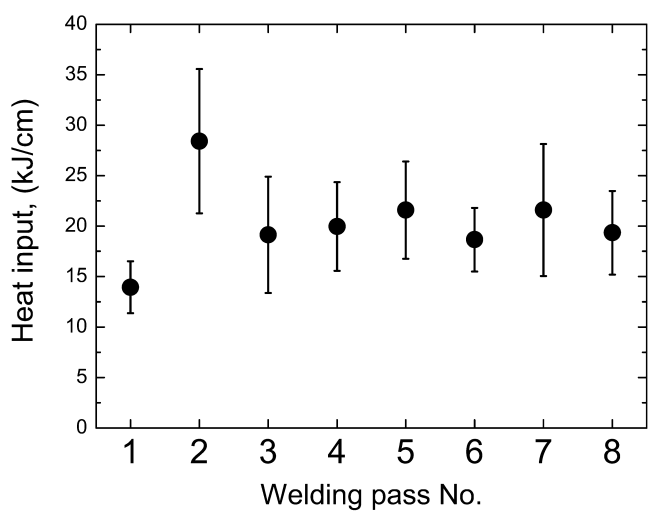

(a) Heat input

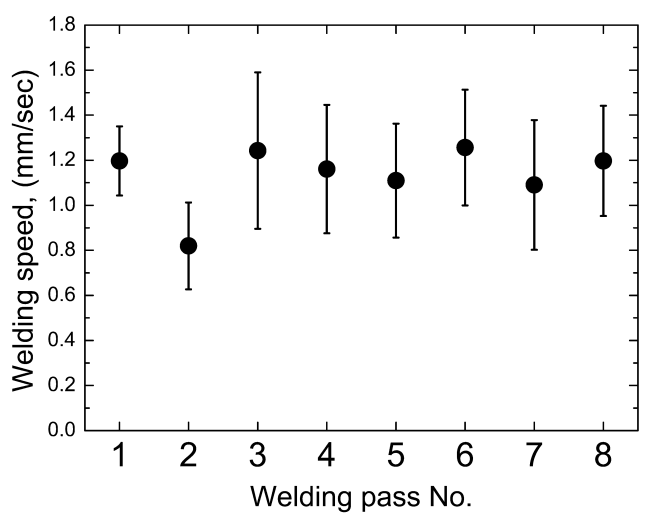

(b) Welding speed

Fig. 5 Average and standard deviation of welding conditions for each welding pass.

\section{3. 結果及び考察}

\section{1 溶接条件の測定結果}

溶接部試験体を製作した際に取得した入熱量と溶接速度 の平均及びその標準偏差を Fig. 5 に示す。この図は，製作 した10体の試験体に対して，パス間ごとの入熱量及び溶接 速度のばらつきを示している. 入熱量が大きいと溶接速度
が遅くなるなどの相関が見られる．解析では両者の影響を 独立に評価するため，入熱量を単位時間で割った值からモ デルに与える入熱量パラメータ $\mathrm{Q}$ を求めた。なお， 1 パス の溶接を施す間，すなわち 1 パスごとの溶接開始から終了 までの電流, 電圧及び溶接速度の変動は, 溶接試験体ごと のばらつきに比べて無視できるほど小さいことを別途確認 している．溶接条件のばらつきは，配管口径，開先形状や 
製造メーカ等により異なると考えられるため，今後データ を拡張して取得する予定である。

\section{2 残留応力解析結果}

\subsection{1 解析手法の妥当性検討}

溶接条件の測定結果に基づく入熱量，溶接速度等の溶接 条件を用いて実施した非定常伝熱解析から得られた温度履 歴を実測值と比較して Fig. 6 に示す。ここで比較している 温度は，溶接線中央から $15 \mathrm{~mm}$ 及び $25 \mathrm{~mm}$ の位置における 外表面の值である。また図中の右上には，分かりやすさの

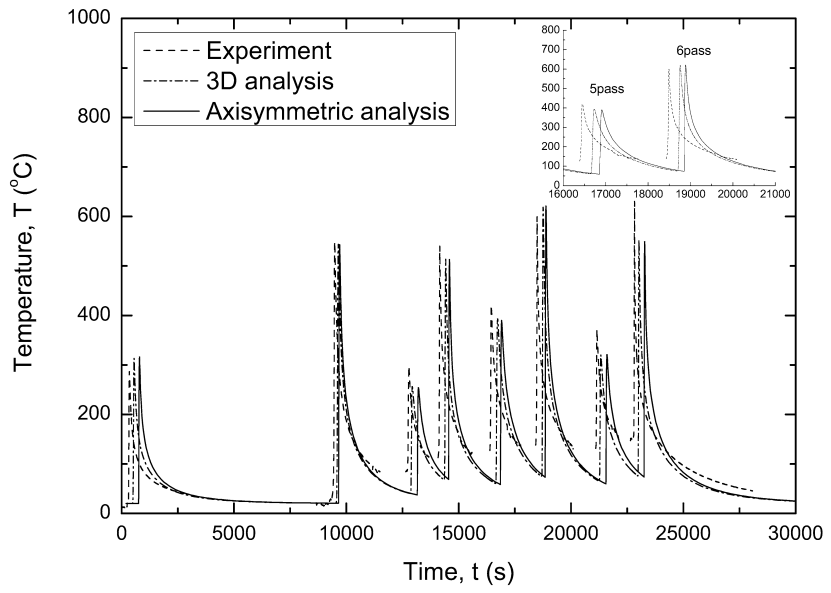

(a) $15 \mathrm{~mm}$ from welding center
ためスケールを拡大した図も示している。三次元及び軸対 称モデルを用いて求めた温度履歴は，最高到達温度及び冷 却速度ともに実測值とほぼ一致している。この結果から， 本研究で用いた伝熱解析は，溶接を十分な精度で再現でき ていることが確認できた。

この温度履歴を用いた熱弾塑性解析により求めた溶接残 留応力の精度を確かめるため, 配管内表面及び外表面を対 象として，三次元及び軸対称モデルによる残留応力解析結 果を実測值と比較して Fig. 7 に示す. 残留応力の実測值は, 内表面は応力解放法，外表面は応力解放法と X 線回折法に

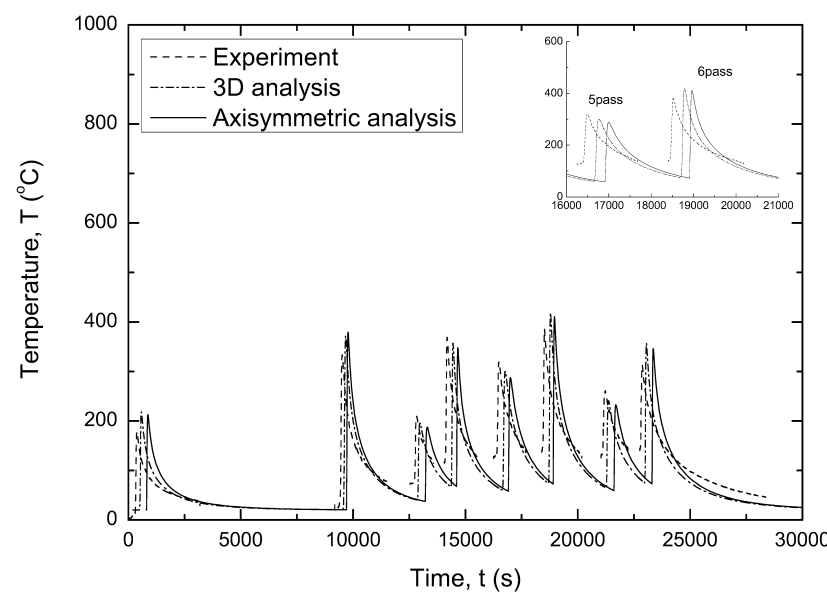

(b) $25 \mathrm{~mm}$ from welding center

Fig. 6 Temperature history recorded at the outer surface near the weld.
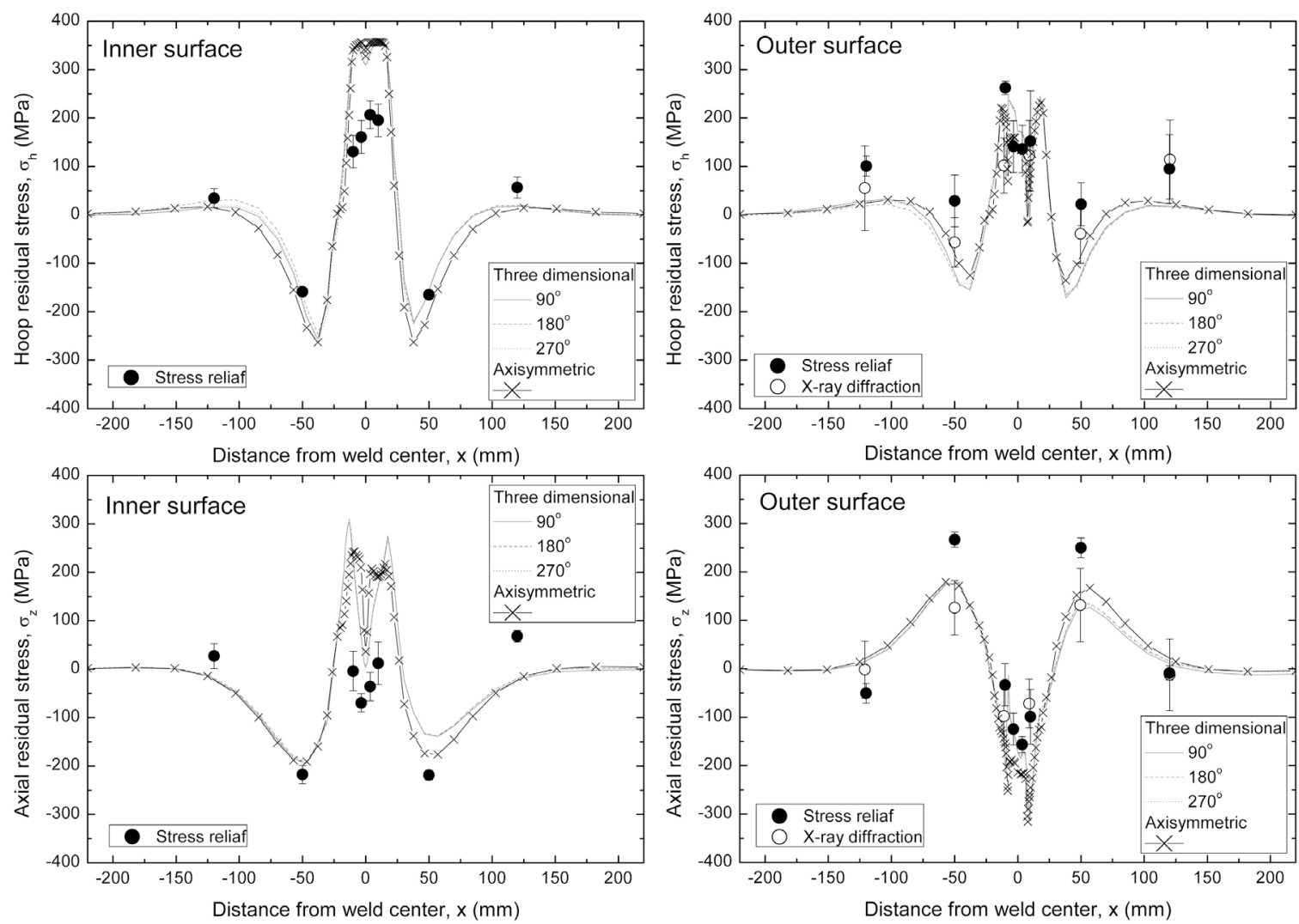

Fig. 7 Comparison between analytical results and X-ray diffraction and stress relief measurements in residual stress distribution at the inner and outer surfaces. 


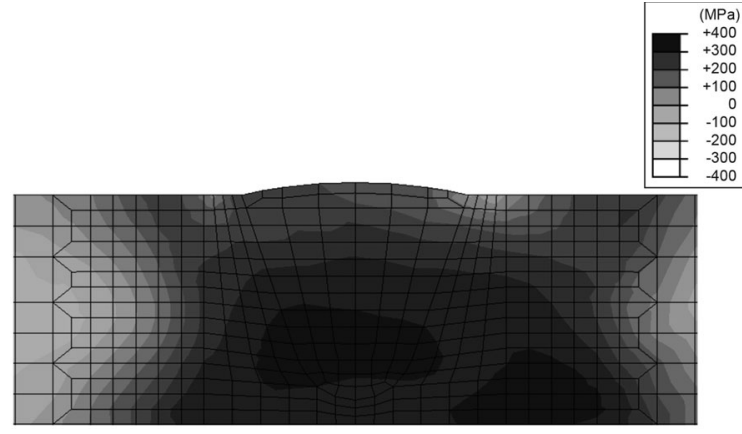

(a) Hoop stress (three dimensional)

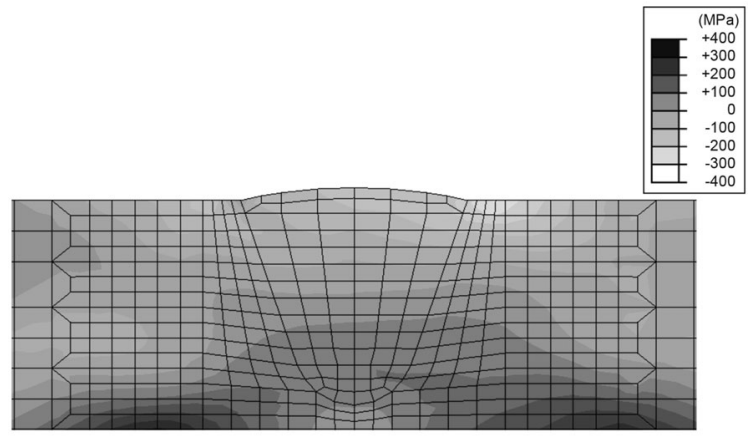

(c) Axial stress (three dimensional)

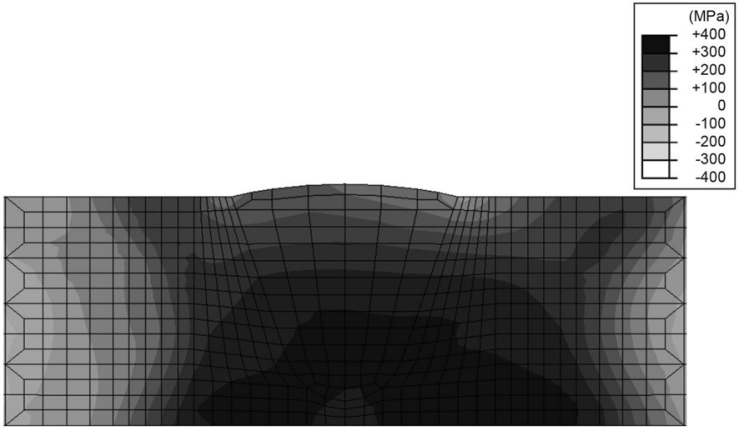

(b) Hoop stress (axisymmetric)

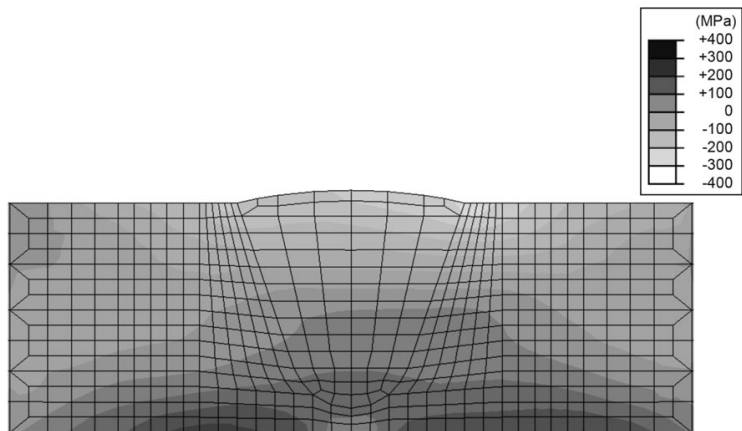

(d) Axial stress (axisymmetric)

Fig. 8 Comparison of weld residual stress distributions near the welded zone between three dimensional and axisymmetric analyses.

より得られた結果である。三次元モデルの解析結果につい ては，溶接始終端を $0^{\circ}$ として $90^{\circ}, 180^{\circ}$ 及び $270^{\circ}$ の位置 に拈ける残留応力分布を示している。測定方法や測定精度 等に伴う実測值のばらつきに比べて，実測值と三次元モデ ルによる解析結果の差は同等か，それよりも小さいと考え られることから，両者はよく一致していると言える，すな わち, 溶接部近傍の周方向残留応力は，内表面及び外表面 ともに引張応力である。 また，軸方向残留応力は，内表面 に引張応力，外表面に圧縮応力が発生しており，これらは よく知られる分布 ${ }^{7-11}$ と同様の分布である。また，三次元解 析の結果において, $90^{\circ}$ から $270^{\circ}$ の範囲の残留応力は, ほ ぼ等しい值となっていることが分かる，さらに，この図を 基に三次元モデルと軸対称モデルを比較すると, 三次元モ デルの $90^{\circ}$ から $270^{\circ}$ の範囲の解析結果と軸対称モデルによ る解析結果は, 要素の大きさの違いや, 軸対称モデルにお いて面外変形を考虑していないことに伴う違いはあるもの の，両者ともよく一致することが確認できた.

なお，三次元解析に扔いて，溶接始終端付近の残留応力分 布は溶接定常部と明らかに異なり, 溶接終端付近の $330^{\circ}$ か ら $355^{\circ}$ 付近に高い引張応力が発生し, 溶接始端前方の $5^{\circ}$ か ら $15^{\circ}$ 付近に圧縮応力が発生していた。この結果は, Katsuyama ら ${ }^{12)}$ や Iwamatsu $~^{13}$ による報告とも一致しており， 本解析手法の妥当性及び精度は確かめられたと考えられる.

\subsection{2 軸対称モデルによる板厚内残留応力分布}

軸対称モデルによる解析の妥当性について，板厚内の残 留応力を三次元モデルの結果と比較することにより検討す る. 三次元モデルと同じ溶接条件で解析した場合の溶接部

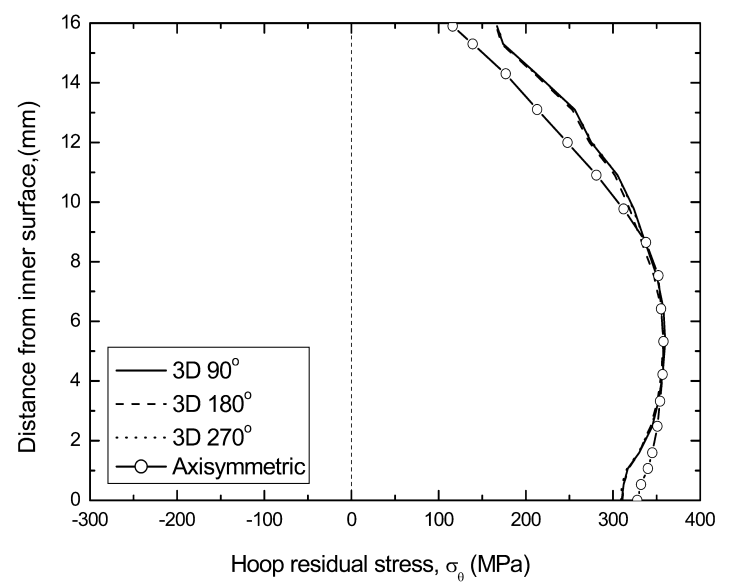

(a) Hoop

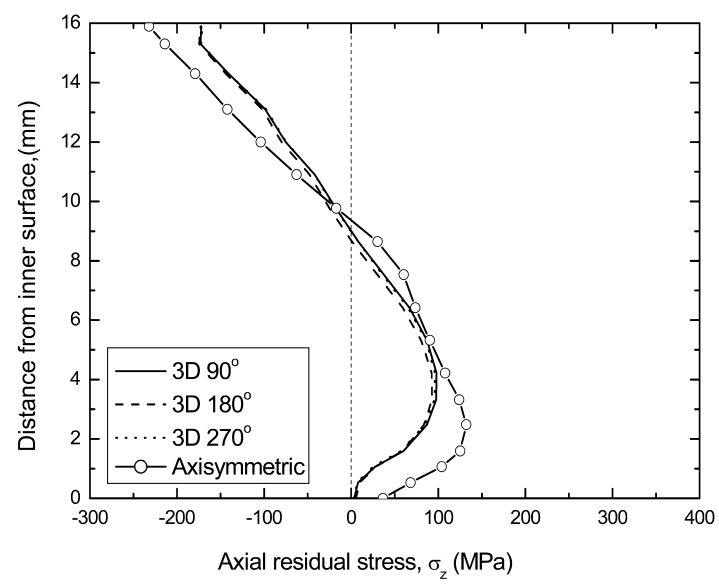

(b) Axial

Fig. 9 Comparison of through-thickness distributions of residual stress at the weld center between three dimensional and axisymmetric analyses. 


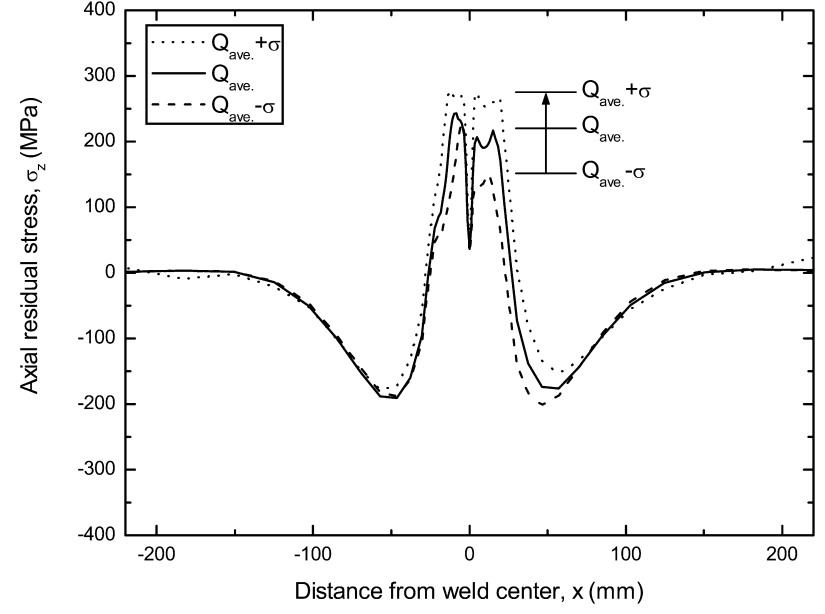

(a) Inner surface

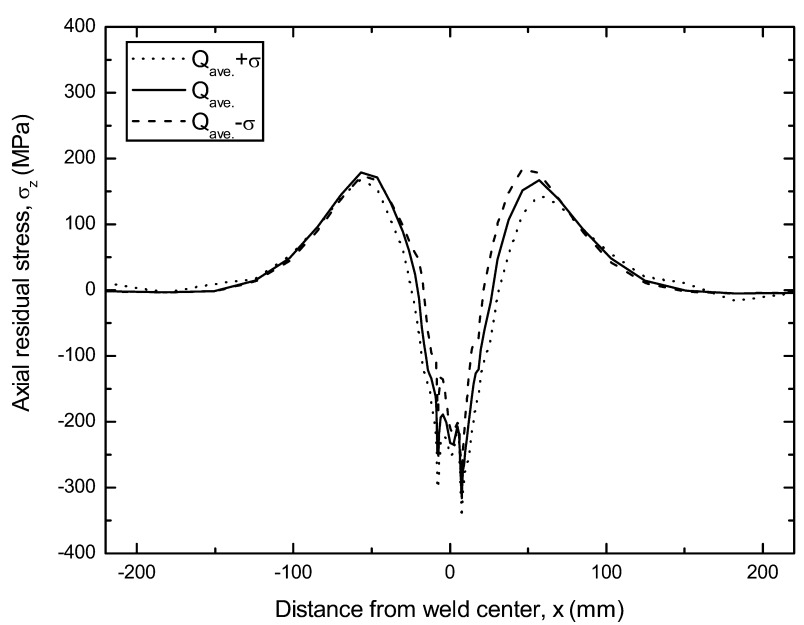

(b) Outer surface

Fig. 10 Effect of heat input of last welding pass on weld residual stress at the inner and outer surfaces.

近傍の周方向及び軸方向の残留応力分布を Fig. 8 に示す. また，溶接線中央断面における内表面から外表面への応力 分布を Fig. 9 に示す.これらの図から明らかなように，同 一の溶接条件による三次元モデルと軸対称モデルによる解 析結果を比較すると, 溶接残留応力分布の傾向はよく一致 している. 残留応力の值について詳細に比較すると, 両者 はほぼ一致するものの，場所によっては $50 \mathrm{MPa}$ 程度の差が 見られる. 文献14において, 両者で求められた残留応力分 布を用いて SCC 進展解析を行った場合, 軸対称モデルによ る SCC 進展速度は，三次元モデルと同等か，あるいは速い ため, 保守的に評価可能であることが示されている．した がって, 軸対称モデルによる溶接残留応力シミュレーショ ンは, 溶接条件に関するパラメトリック解析を通して, 溶 接残留応力評価モデルの作成に有用である.

\subsection{3 溶接条件が残留応力に及ぼす影響}

溶接条件のばらつきが残留応力分布に及ぼす影響を把握 するため, 軸対称モデルを用いて, 試験体製作時に取得し た溶接条件（入熱量及び溶接速度）を基に，溶接条件を変

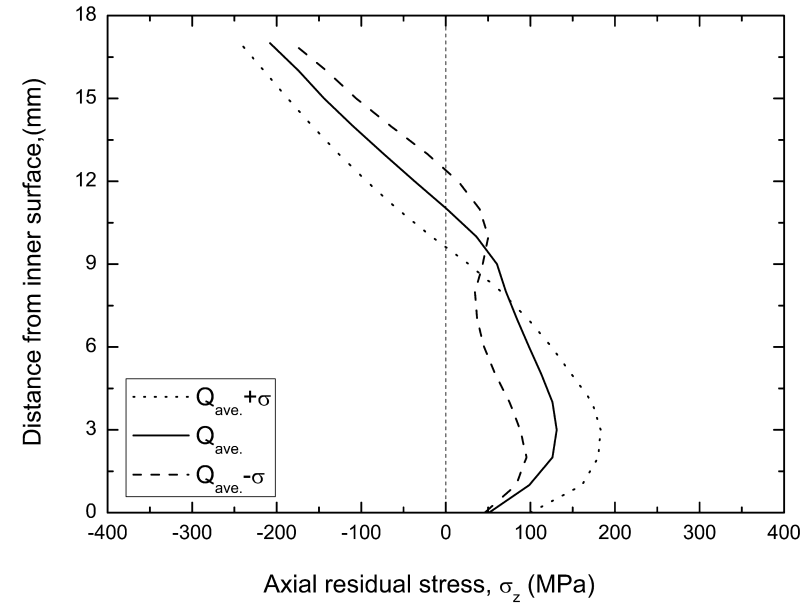

(a) Weld center

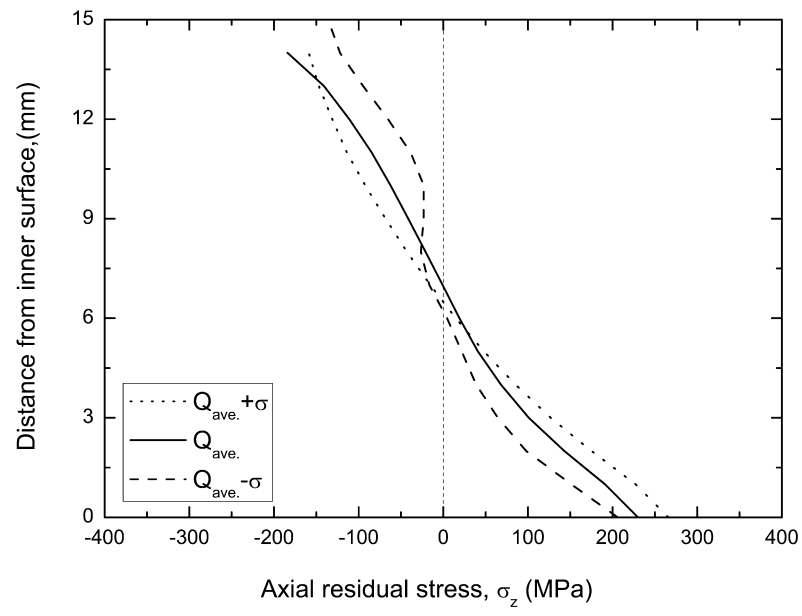

(b) Cross section at the maximum stress, $\sigma_{z}^{\max }$

Fig. 11 Effect of heat input of last welding pass on through-thickness distribution of axial residual stress at the weld center and cross sections at maximum axial stress.

化させて 108 ケースのパラメトリック解析を行った。ここ で，オーステナイト系ステンレス鋼管突合せ溶接部におい て顕在化している SCC のほとんどは周方向き裂であり，軸 方向応力がその発生及び進展に影響を及ぼすため，以降は 軸方向応力に着目して解析結果を述べる。なお， 1 パス目 （初層）の溶接条件を変化させた場合，溶融池の溶け込み深 さ，塑性歪分布や内表面の半径方向の収縮変形は多少異な るものの, 最終的な残留応力分布はほとんど変化しなかっ た。このため， $250 \mathrm{~A}$ 配管のような比較的薄肉の配管におい ては，初層における溶接条件変化の影響は，2 パス目以降 の溶接により低減し，ほとんど残らないことが確認できた. 最終パスの 8 パス目における入熱量を変化させた場合の内 外表面の溶接残留応力分布を Fig. 10 に示す.ここで, 8 パ ス目以外の入熱量と溶接速度は平均值で固定している。 入 熱量が増加するほど，引張応力が生じる領域が広くなると ともに，内表面における軸方向の引張応力は増加し，外表 面の圧縮応力も増加する. 同様に板厚内の溶接残留応力分 布を Fig. 11 に示す．同図の (a) は溶接中央断面，及び (b) は 


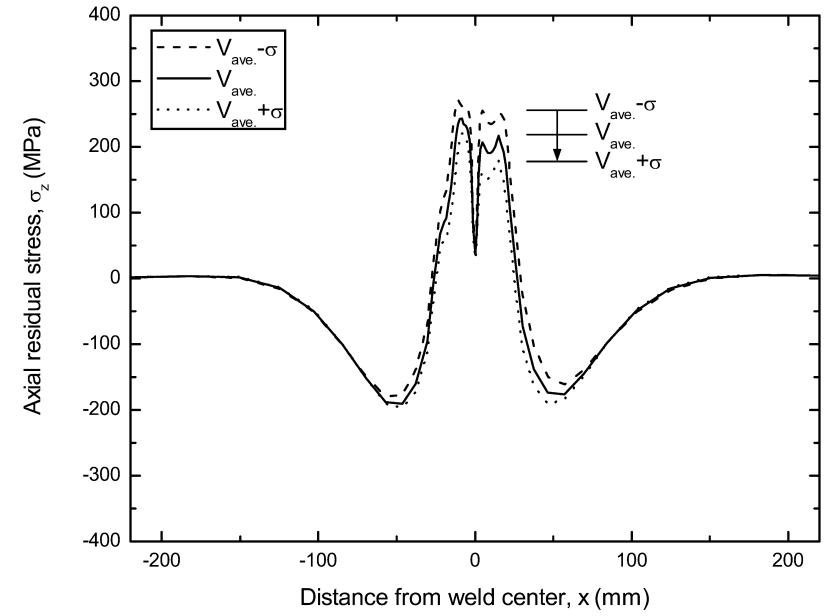

(a) Inner surface

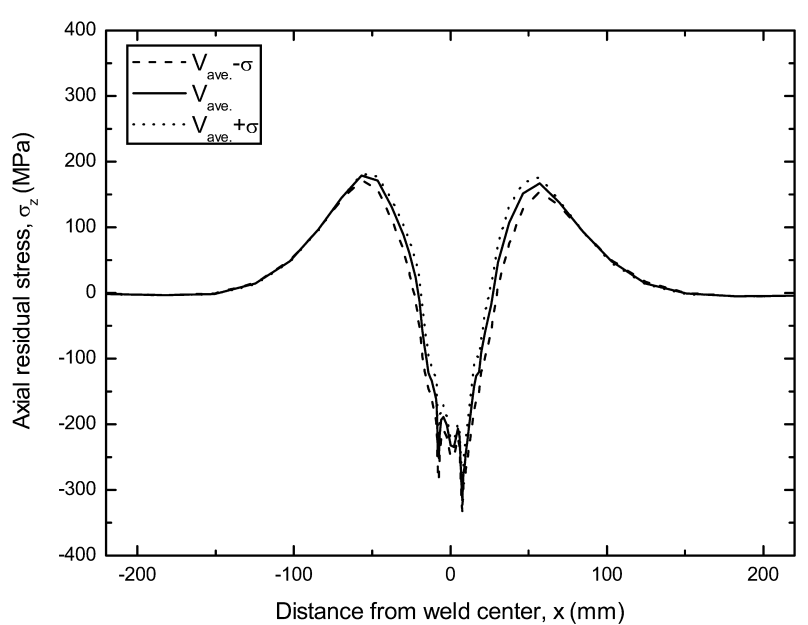

(b) Outer surface

Fig. 12 Effect of welding speed of last welding pass on weld residual stress at the inner and outer surfaces.

内表面において軸方向応力が最大（ $\sigma_{\mathrm{z}}{ }^{\max }$ と称する）となる 断面の軸方向応力分布を示している．溶接金属の余盛や溶 接変形のため肉厚の違いが見られるものの, 両断面とも, 内表面付近の引張応力は入熱量が増加するとともに増加し, 外表面付近の圧縮応力も増加することが分かる.

一方，溶接速度の影響について，8 パス目の溶接速度の みを変化させて解析を行った場合の, 内外表面における残 留応力分布及び断面内の軸方向応力分布をそれぞれ Fig. 12 及び Fig. 13 に示す.これらの図から明らかなように, 溶接 速度が速くなるに従い, 引張応力が生じる領域が狭くなる とともに, 内表面付近の引張応力が減少し, 外表面付近の 圧縮応力も減少する。なお，軸対称モデルの場合，全周に わたって溶接による入熱が同時に与えられることとなるが, 三次元モデルにより溶接熱源の移動を考慮した解析を行っ た場合でも，同様の結果が得られた。すなわち，溶接速度 の影響は，入熱量のそれとほぼ反比例の関係にあることが 確認された。これは，溶接速度が速くなるほど単位時間当 たりの入熱量が減少するためと考えられる.

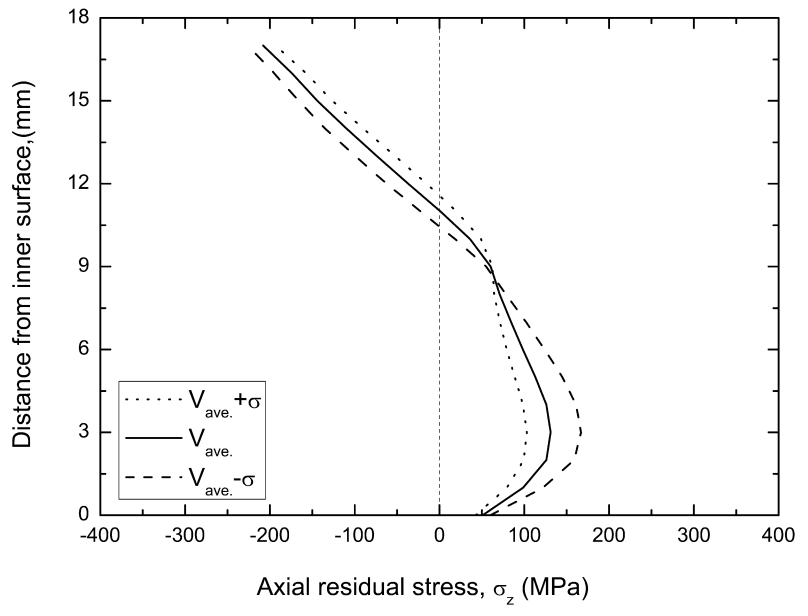

(a) Weld center

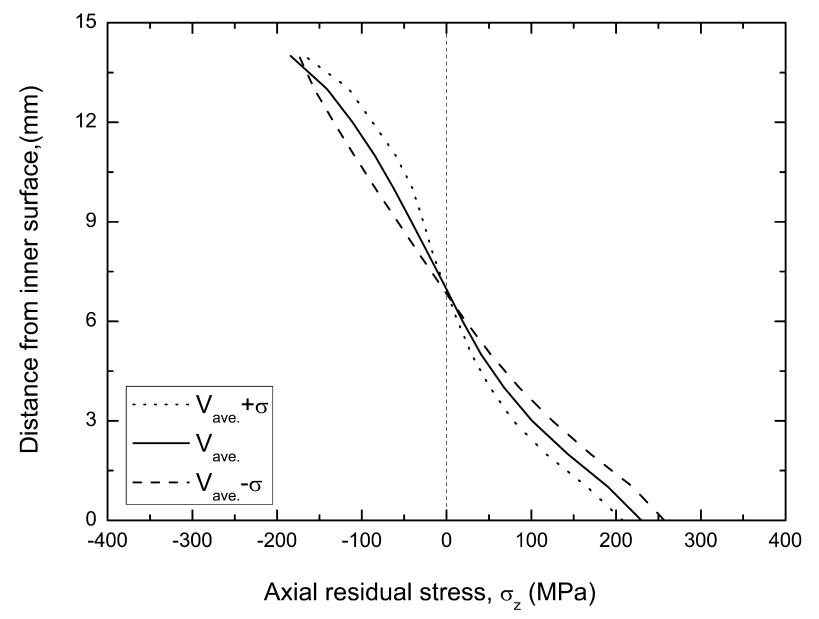

(b) Cross section at the maximum stress, $\sigma_{2}^{\text {max }}$

Fig. 13 Effect of welding speed of last welding pass on throughthickness distribution of axial residual stress at the weld center and cross section at maximum axial stress .

以上の知見を踏まえ，溶接パスごとに溶接条件を変化さ せたパラメトリック解析の結果を取りまとめてデータベー スを作成した。データベースには，各位置における残留応 力のばらつきが正規分布に従うと仮定して統計処理により 求めた各位置の残留応力の平均值, 標準偏差, 及び近隣座 標同士の相関係数を格納した.

\subsection{PFM 解析結果}

PFM 解析において用いる溶接残留応力分布は，前節で作 成したデータベースから次のように決定する。まず，各位 置の残留応力を, 近隣座標の相関を加味した正規分布に従 うと仮定して，ある值に決定する，次に，決定した各位置 の残留応力を用いて，板厚方向の分布を最小自乗法により 4 次多項式に近似する。この 4 次多項式は, SCC 進展評価 の際に影響関数法により応力拡大係数を算出するためのも のである.このようにデータベースから 4 次多項式の残留 応力分布を求める手続きを, 乱数を発生させて何度も繰り 返すことにより，確率論的に残留応力分布のばらつきを模 


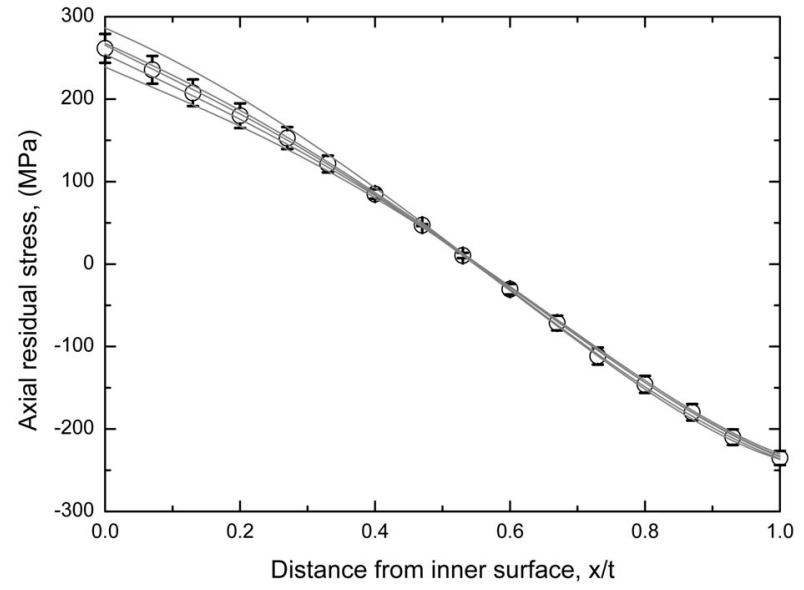

Fig. 14 Simulated residual stress distribution and the scatter of residual stress at the cross section of $1.63 \mathrm{~mm}$ away from fusion boundary where the SCCs were observed most frequently ${ }^{5}$.

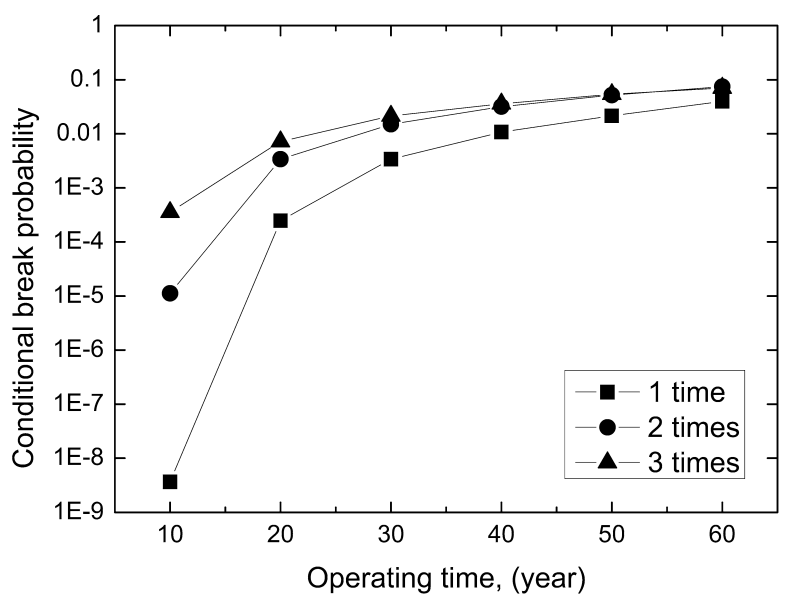

Fig. 15 PFM analysis results for the effect of uncertainties in residual stress distribution on break probabilities of piping.

擬することとした.

$\mathrm{SCC}$ の実測データ ${ }^{5}$ に基づき，き裂発生確率が最も高い断 面を求め，その断面における残留応力分布のばらつきを模 擬した例を Fig. 14 に示す。図中のエラーバーはパラメトリ ック解析の結果から得られた各位置の標準偏差である.こ の図から分かるように，溶接残留応力のばらつきは位置ご とに異なり，本研究で対象とした $250 \mathrm{~A}$ 配管溶接部では, 内表面の標準偏差が大きくなる一方，板厚内の標準偏差は 小さい傾向が見られた。溶接条件のばらつきが変化する場 合，この標準偏差に及ぼす影響も位置ごとに異なると考え られるが，本研究では基本的な影響確認を行うため，すべ ての位置の標準偏差を 2 倍, 3 倍と変化させて PFM 解析を 行い，溶接残留応力分布のばらつきが破断確率に及ぼす影 響を評価した。得られた破断確率の解析結果を Fig. 15 に示 す. 残留応力のばらつきが大きくなるほど, 配管が破断に 至る確率は増加している. 特に, 運転年数が短く, 破断確 率の低い場合にそのばらつきの影響が大きいことが分かる. これは，残留応力のばらつきが大きくなるほど，進展速度
が速く，破断に至りやすい SCC が多く現れてくるためであ ると考えられる．文献14における決定論的評価においても， 入熱量が大きくなるほど，あるいは溶接速度が遅くなるほ ど，内表面及び板厚内における軸方向の引張応力が増加す ることにより，配管が破断に至る時間が短縮されることが 示されている. Fig. 15 に示した破断確率の変化は, 残留応 力のばらつきが大きくなることにより，この傾向が顕著に 現れているものと考えられる.

\section{4. 結言}

（1）配管溶接部試験体（SUS316 250 A sch 80 管）を10体製 作し, 入熱量や溶接条件等の溶接条件のばらつきを把 握するとともに，各試験体の残留応力分布を実測によ り評価した。

（2）配管溶接部試験体に対して三次元及び軸対称モデルに よる溶接シミュレーションを行い，実測值と比較する ことにより解析手法の妥当性を確認した。また，溶接 残留応力分布のばらつき評価に関して，軸対称モデル による溶接残留応力解析が有用であることを確認した。

（3）溶接条件を変化させた解析により，溶接残留応力に及 ぼす入熱量及び溶接速度の影響を評価した。その結果， 今回対象とした $250 \mathrm{~A}$ 配管のように比較的薄肉の配管 では, 最終溶接パスの溶接条件が残留応力分布に及ぼ す影響が大きいことを示した。

（4）軸対称モデルによるパラメトリック解析の結果に基づ く残留応力評価モデルを用いて PFM 解析を実施し，残 留応力のばらつきが大きくなるほど，配管が破断に至 る確率は増加することを定量的に示した。

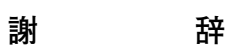

本報告は，平成18年度及び平成19年度に（独）日本原子 力研究開発機構が経済産業省原子力安全・保安院から「確 率論的構造健全性評価調査」として受託した事業における 成果の一部である。

\section{参 考 文 献}

1) G. Yagawa, Y. Kanto, S. Yoshimura, et al.: "Probabilistic Fracture Mechanics Analysis of Nuclear Structural Components: A Review of Recent Japanese Activities," Nuclear Engineering and Design, 207 (2001), pp. 269-286.

2) H. Itoh, J. Katsuyama and K. Onizawa: "A Probabilistic Evaluation Model for Welding Residual Stress Distribution at Piping Joint in Probabilistic Fracture Mechanics Analysis," Proceedings of the 2008 ASME Pressure Vessels and Piping Conference, Chicago, U.S.A., PVP2008-61421 (2008).

3) Dassault Systemes Simulia Corp.: ABAQUS user's manual, version 6.7 (2007)

4) J. Goldak, A. Chakravarti, and M. Bibby: "A New Finite Element Model for Welding Heat Sources," Metallurgical Transactions B, 15B (1984), pp. 299-305. 
5) Nuclear and Industrial Safety Agency (NISA): "Report on Evaluation Method for Structural Integrity of Primary Loop Recirculation System," (2004). (in Japanese)

6) Japan Society of Mechanical Engineers (JSME): "Codes for Nuclear Power Generation Facilities - Rules on Fitness-for-Service for Nuclear Power Plants -," JSME S NA1-2004, (2004). (in Japanese)

7) E. F. Rybicki, P. A. McGuire, E. Merrick and J. Wert: "The Effect of Pipe Thickness on Residual Stresses due to Girth Welds," Transactions of the ASME, Journal of Pressure Vessel Technology, Vol. 104 (1982), pp. 204-209.

8) S. Fricke, E. Keim and J. Schmidt: "Numerical Weld Modeling - A Method for Calculating Weld Induced Residual Stresses," Nuclear Engineering and Design 206 (2001) pp. 139-150.

9) R. Bradford: "Through-thickness Distributions of Welding Residual Stresses in Austenitic Stainless Steel Cylindrical Butt Welds," Proceedings of Residual Stresses-ICRS (2000).

10) J. Katsuyama, M. Mochizuki, R. Higuchi and M. Toyoda: "Parametric FEM Evaluation of Residual Stress by Circumferential Welding for Austenitic Stainless Steel," Proceedings of the ASME
Pressure Vessels and Piping Conference, PVP2005-71440 (2005).

11) M. Mochizuki, J. Katsuyama and M. Toyoda: "Effect of Geometrical and Welding Conditions on Through-Thickness Residual Stress," Proceedings of the ASME Pressure Vessels and Piping Conference, PVP2006-ICPVT11-93489 (2006).

12) J. Katsuyama, M. Mochizuki, R. Higuchi and M. Toyoda: "Numerical Analysis of Residual Stress at Unsteady Region of Piping Butt-Welding and Repair-Welding," Proceedings of Japan Welding Society, Vol. 77 (2005), pp. 446-467.

13) F. Iwamatsu, S. Aoike, Y. Fukuta and O. Saitou: "SCC Test Verification of Effect of Moving Heat Source on FEM Evaluation for Weld Residual Stress of Butt-Weld Pipe," Proceedings of the ASME Pressure Vessels and Piping Conference, PVP2009-77897 (2009).

14) J. Katsuyama, T. Tobita, H. Itoh and K. Onizawa: "Effect of Welding Conditions on Residual Stress and SCC Behavior at ButtWelding Joints of Recirculation Pipes," Proceedings of the ASME Pressure Vessels and Piping Conference, PVP2008-61430 (2008). 